\title{
On Some Octocorallia (Alcyonacea) from Hong Kong, with Description of a New Species, Paraminabea rubeusa ${ }^{1}$
}

\author{
Y. Benayahu ${ }^{2,4}$ and K. Fabricius ${ }^{3}$
}

\begin{abstract}
Octocorals from Hong Kong were studied at 18 sites down to a depth of $25 \mathrm{~m}$ in 1999. The collection of $\sim 90$ specimens yielded nine species distributed in seven genera of the families Alcyoniidae, Nephtheidae, and Xeniidae (all are new zoogeographical records for Hong Kong), plus ca. 70 samples of azooxanthellate octocorals of the genera Dendronephthya (family Nephtheidae), Chironepbthya, and Nephtbyigorgia (family Nidaliidae), which were not identified to species level. The collection included Paraminabea rubeusa Benayahu \& Fabricius, n. sp., which is described here. The impoverished nature of the zooxanthellate octocorals is reflected in the low number of species found in the families Alcyoniidae and Xeniidae (seven and one, respectively), families that typically contribute a high proportion of species in the Indo-Pacific region. It is crucial to implement effective conservation policies in Hong Kong to preserve its remaining zooxanthellate octocoral species and thereby prevent the local extinction of these species, including the newly described Sarcophyton tumulosum Benayahu \& Ofwegen, 2009, and Lobophytum mortoni Benayahu \& Ofwegen, 2009, which may be endemic to the region.
\end{abstract}

Hong Kong (latitude $22^{\circ} \mathrm{N}$ ) represents a marginal environment for corals within the South China Sea (Morton and Blackmore 2001). Its coral communities are nonreefbuilding communities, due to winter seawater temperature minima averaging $17^{\circ} \mathrm{C}$ (with occasional brief drops to $14-16^{\circ} \mathrm{C}$ in surface waters), and freshwater intrusions frequently reducing salinity. Furthermore, the reefs of Hong Kong are affected by a variety of anthropogenic perturbations that have led to their gradual deterioration (e.g., Morton 1994, 2002). The stony corals of Hong

${ }^{1}$ Manuscript accepted 1 February 2009.

${ }^{2}$ Department of Zoology, George S. Wise Faculty of Life Sciences, Tel Aviv University, Ramat Aviv 69978, Tel Aviv, P.O.B 39040, Israel.

${ }^{3}$ Australian Institute of Marine Science (AIMS), PMB No. 3, Townsville MC, Queensland 4810, Australia.

${ }^{4}$ Corresponding author: (phone: 972-3-6409090; fax: 972-3-6409403; e-mail: Yehudab@tauex.tau.ac.il).

Pacific Science (2010), vol. 64, no. 2:285-296

doi: $10.2984 / 64.2 .285$

(C) 2010 by University of Hawai'i Press

All rights reserved
Kong have been studied extensively and are considered subtropical formations (e.g., Clark 1998, McCorry 2002, Lam et al. 2007, and references therein). Notably, coral cover has declined to low levels in several areas, apparently due to impaired coral recruitment (McCorry 2002).

Taxonomic studies of the Hong Kong Octocorallia have recently been reviewed by Lam and Morton (2008). Those studies were initiated in 1854 during the North Pacific Exploring Expedition by Stimpson (1855), who described the new species Nephthya coccinea, which was placed in Echinomuricea by Nutting (1910). They were followed by Verrill $(1865 a, b)$, who identified and described a further six new species from the specimens collected earlier by Stimpson. Later, Shen (1940) described Dendronephthya sp. and Nephtbya sp. from Hong Kong. After a gap of $40 \mathrm{yr}$ in the study of octocorals from the area, Zou and Scott (1982) surveyed the gorgonians from the northeastern part of Hong Kong, recording a total of 26 species belonging to 15 genera and six families: Anthothelidae (one species), Subergorgiidae (two species), Acanthogorgiidae (three species), Paramuriceidae (12 species), Plexauridae (five 
species), and Ellisellidae (three species). Based on a collection conducted in Hong Kong during 1980, $\mathrm{Li}$ (1986) recorded the families Alcyoniidae (six species) and Nephtheidae (four species), all of which were new records from China. Based on a collection carried out in 1995, Clark (1997) listed several octocorals in the Cape d'Aguilar Marine Reserve (Hong Kong) in the families Paramuriceidae (nine species), Telestidae (one species), Plexauridae (three species), Ellisellidae (two species), and Alcyoniidae (two species), including two new records for the region. Based on a survey conducted in 1999 on the shallow reefs of Hong Kong, Fabricius and McCorry (2006) listed 42 octocoral species distributed among 23 genera of the families Alcyoniidae (six species), Nephtheidae (six species), Nidaliidae (two species), Xeniidae (one species); Acanthogorgiidae (four species), Plexauridae (18 species), and Ellisellidae (three species). Most of the taxa mentioned in the study were not identified to species level and are referred to as sp. (see table 2 of Fabricius and McCorry 2006). That survey presented results on the abundance of zooxanthellate and azooxanthellate octocorals along the main spatial and water quality gradients in Hong Kong, and the authors concluded that the former are strongly affected by water clarity and that their disappearance is associated with a dramatic reduction in stony coral communities. Recently, Lam and Morton (2008) reported 22 octocoral species from two submarine caves in the oceanic southeastern waters of Hong Kong, including one new species, Paraminabea bongkongensis Lam \& Morton, and an additional 11 species that were new records for the region. In addition, that study presented a list of 60 octocorals previously recorded from Hong Kong.

The study reported here deals with octocorals of the families Alyconiidae, Nephtheidae, and Xeniidae from Hong Kong collected by us in 1999 . We provide a systematic list of the species and describe a new species, Paraminabea rubeusa Benayahu \& Fabricius. Notably, this collection has recently yielded two other new species, Lobophytum mortoni Benayahu \& Ofwegen, 2009, and Sarcopbyton tumulosum Benayahu \& Ofwegen, 2009.
MATERIALS AND METHODS

Collection of material was conducted during November 1999 and comprised the following 18 sites in Hong Kong: Bokhara Rocks (22 $\left.13^{\prime} 25.71^{\prime \prime} \mathrm{N}, 114^{\circ} 16^{\prime} 45.09^{\prime \prime} \mathrm{E}\right)$; Tai Tau Chau (Shek O) $\left(22^{\circ} 13^{\prime} 56.63^{\prime \prime} \mathrm{N}, 114^{\circ} 15^{\prime}\right.$ $\left.10.19^{\prime \prime} \mathrm{E}\right)$; Sham Wan (22 $23^{\prime} 05.59^{\prime \prime} \mathrm{N}$, $\left.114^{\circ} 08^{\prime} 30.49^{\prime \prime} \mathrm{E}\right) ;$ Pak Shau (Round Island) $\left(22^{\circ} 32^{\prime} 25.45^{\prime \prime} \mathrm{N}, 114^{\circ} 19^{\prime} 51.58^{\prime \prime} \mathrm{E}\right)$; Tsung O Wan (Junk Bay) (22 $16^{\prime} 39.48^{\prime \prime} \mathrm{N}, 114^{\circ}$ $\left.15^{\prime} 12.45^{\prime \prime} \mathrm{E}\right)$; Kung Chau (22 $28^{\prime} 56.91^{\prime \prime} \mathrm{N}$, $\left.114^{\circ} 22^{\prime} 14.18^{\prime \prime} \mathrm{E}\right)$; Ping Chao (22 $32^{\prime} 22.30^{\prime \prime}$ $\left.\mathrm{N}, 114^{\circ} 23^{\prime} 31.32^{\prime \prime} \mathrm{E}\right)$; Breakers Rock $\left(22^{\circ} 28^{\prime}\right.$ $\left.39.52^{\prime \prime} \mathrm{N}, 114^{\circ} 5^{\prime} 13.72^{\prime \prime} \mathrm{E}\right)$; Lo Chau Mun (Po Toi Channel) $\left(22^{\circ} 11^{\prime} 23.31^{\prime \prime} \mathrm{N}, 114^{\circ}\right.$ $\left.15^{\prime} 26.85^{\prime \prime} \mathrm{E}\right)$; Waglan (22 ${ }^{\circ} 11^{\prime} 02.61^{\prime \prime} \mathrm{N}$, $114^{\circ} 18^{\prime} 19.16^{\prime \prime} \mathrm{E}$ ); Pak Kwo Chau (North Ninepin) (22 $15^{\prime} 26.23^{\prime \prime} \mathrm{N}, 114^{\circ} 21^{\prime} 00.26^{\prime \prime}$ E); Nam Kwo Chau (South Ninepin) (22 $35^{\prime} 15.05^{\prime \prime} \mathrm{N}, 114^{\circ} 20^{\prime} 49.40^{\prime \prime} \mathrm{E}$ ); Fo Shek Chau (Basalt Island) $\left(22^{\circ} 18^{\prime} 51.08^{\prime \prime} \mathrm{N}, 114^{\circ}\right.$ $22^{\prime}$ 01.20" E); Long Ke Wan (22 $19^{\prime} 12.83^{\prime \prime}$ $\mathrm{N}, 114^{\circ} 22^{\prime} 58.25^{\prime \prime} \mathrm{E}$ ); Mat Chau (Po Toi) $\left(22^{\circ} 10^{\prime} 12.67^{\prime \prime} \mathrm{N}, 114^{\circ} 15^{\prime} 31.02^{\prime \prime} \mathrm{E}\right)$; Nam Kok Tsui (Po Toi South) (22 $12^{\prime} 12.29^{\prime \prime} \mathrm{N}$, $114^{\circ} 15^{\prime}$ 47.62" E); Lo Chau Pak Pai (Castle Rock) (22 $\left.10^{\prime} 30.15^{\prime \prime} \mathrm{N}, 114^{\circ} 14^{\prime} 13.67^{\prime \prime} \mathrm{E}\right)$; Luk Chau (Lamma) (22 $13^{\circ} 42.43^{\prime \prime} \mathrm{N}, 114^{\circ}$ $07^{\prime} 28.42^{\prime \prime}$ E) (Figure 1).

These sites were reached by boat, and a careful examination of a variety of niches was carried out by scuba diving down to 25 m. Approximately 90 samples were collected, encompassing the variety of octocoral taxa found at the various sites. Before collection most of the colonies were photographed in situ. Samples were fixed in $4 \%$ formalin in seawater overnight, then rinsed in freshwater, and transferred to $70 \%$ alcohol. Sclerites were obtained by dissolving the tissues in $10 \%$ sodium hypochlorite and prepared for scanning electron microscopy as follows: the sclerites were carefully rinsed with doubledistilled water, dried at room temperature, coated with gold, and then examined with an electron microscope (Jeol 840A) operated at $25 \mathrm{kV}$. Identification of species was in part facilitated by comparisons with permanent sclerite preparations of type material kept in the Zoological Museum, Department of 


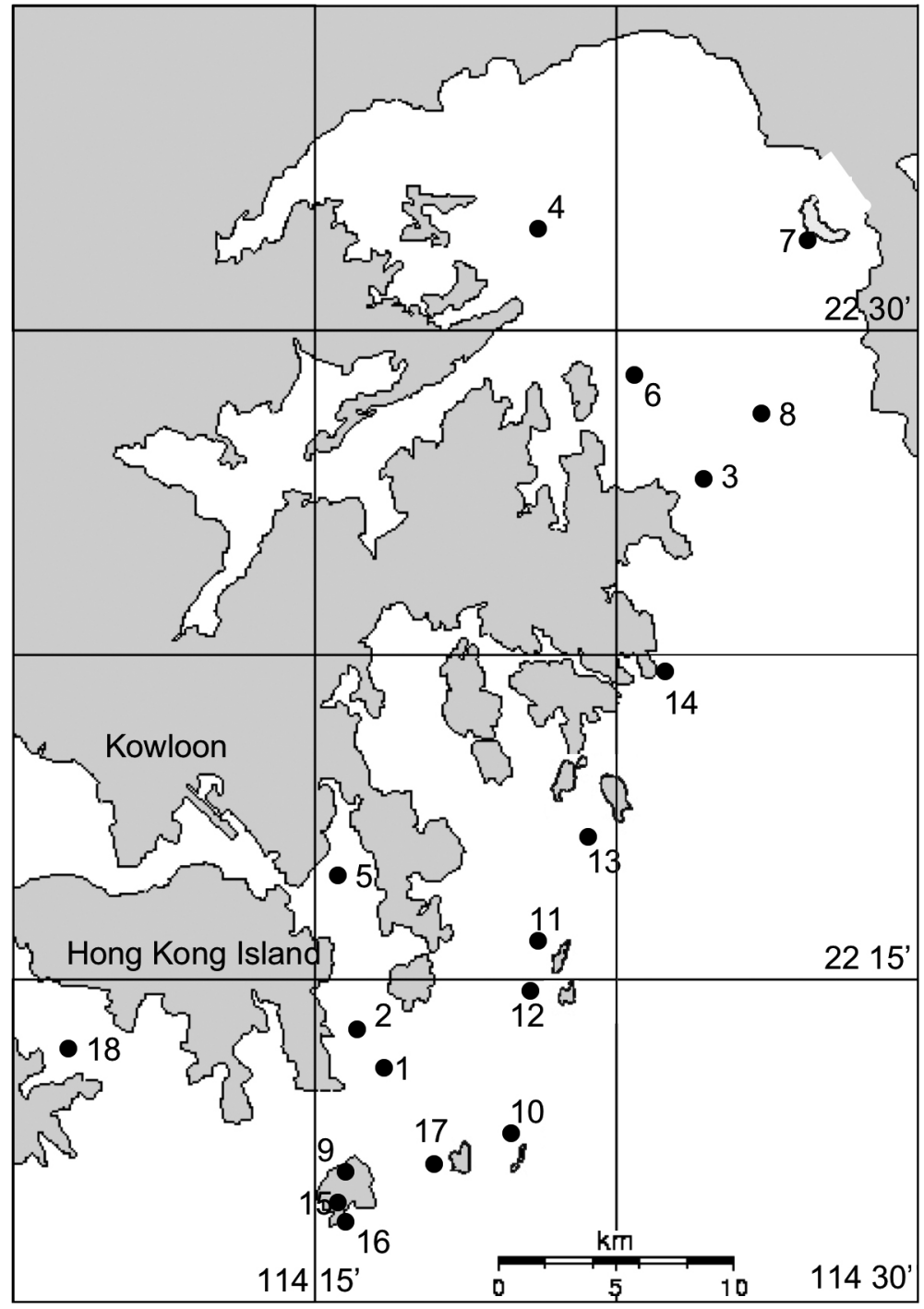

FIgure 1. Map of Hong Kong showing the study sites. 1, Bokhara Rocks; 2, Tai Tau Chau (Shek O); 3, Sham Wan; 4, Pak Shau (Round Island); 5, Tsung O Wan (Junk Bay); 6, Kung Chau; 7, Ping Chao; 8, Breakers Rock; 9, Lo Chau Mun (Po Toi Channel); 10, Waglan; 11, Pak Kwo Chau (North Ninepin); 12, Nam Kwo Chau (South Ninepin); 13, Fo Shek Chau (Basalt Island); 14, Long Ke Wan; 15, Mat Chau (Po Toi); 16, Nam Kok Tsui (Po Toi South); 17, Lo Chau Pak Pai (Castle Rock); 18, Luk Chau (Lamma).

Zoology, Tel Aviv University, Israel (zMTAu). The specimens are deposited in ZMTAU and in Nationaal Natuurhistorisch Museum, Leiden, The Netherlands (RMNH). Members of the families Nephtheidae and Nidaliidae are still being examined.

\section{RESULTS}

The examined material yielded nine species in the three families Alcyoniidae, Nephtheidae, and Xeniidae (Table 1), of which three are new species (Benayahu and Ofwegen 


\section{TABLE 1}

List of Species of Octocorallia of the Order Alcyonacea

(Lamouroux, 1816) from Hong Kong, with Museum Inventory Numbers (zMTAU Co), RMNH Coel

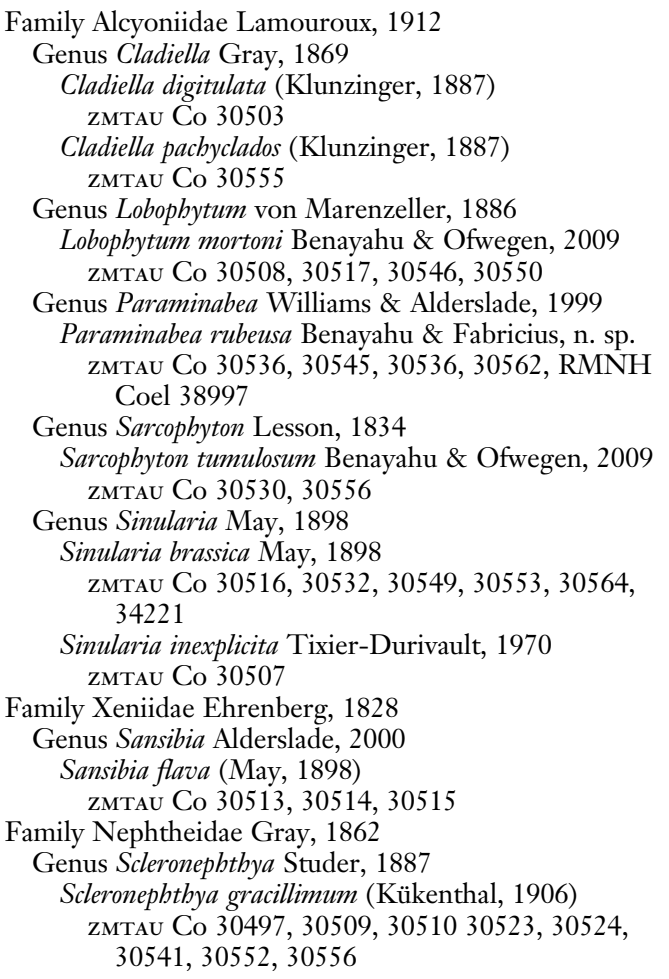

2009; this study) and the other six are new zoogeographical records for Hong Kong. Underwater photographs of some of the octocorals collected in this study are presented.

Paraminabea rubeusa Benayahu \& Fabricius, n. sp.

Figures 2-5, 6a

TYPE MATERIAL: Holotype and four microscope slides (zmTau Co 34221), Waglan, Hong Kong, 16-18 m, 10 November 1999. Six paratypes: zMTAU Co 30545 (two colonies), RMNH Coel 38997 (one colony), same data as holotype; zMTau Co 30562, Bokhara Rocks, Hong Kong, submerged reef, $17 \mathrm{~m}$, 12 November 1999 (one colony); zMTAu Co 30536, Mat Chau (Po Toi), Hong Kong, 18 m, 11 November 1999 (two colonies).
DESCRIPTION: The holotype is an arborescent colony, $60 \mathrm{~mm}$ long and $55 \mathrm{~mm}$ wide (Figure $2 a$ ). Its has a low base, ca. 3-6 mm high, that gives rise to a number of branching primary lobes. Lobes and lobules are fingerlike, stout with tapering ends, and compose most of the total length of the colony. Lobes and lobules are clustered together, with some partially bent. The colony is dimorphic. Some of the autozooids with their white anthocodiae protrude from polyp apertures. Tentacles have 7-12 pinnules each, arranged in one row along each edge. Siphonozooids minute $(>1 \mathrm{~mm}$ in diameter) and hardly visible with the naked eye. There are no sclerites in the polyps.

Surface of lobes with numerous six- and eight-radiates $0.05-0.08 \mathrm{~mm}$ long (Figure 3). Interior of lobes with two types of sclerites, including some radiates similar to those of the surface of the lobes, as well as elongated spindle like sclerites, 0.070-0.095 mm long, with thorns, either pointed or truncated, and a distinct median waist (Figure 4). Uppermost surface of base with similar radiates as on surface of lobes. Interior of base with numerous barrels and a few radiates $0.05-0.09 \mathrm{~mm}$ long (Figure 5). Individual sclerites tinted reddish; when packed densely on surface of lobes, surface of base, and its interior, they provide colony with its red color; interior of lobes is white-beige.

COLOR: Preserved colony is red with white polyps; all sclerites reddish. No zooxanthellae were found in the tissue.

LIVING FEATURES: Red color; expanded autozooids white (Figure $6 a$ ). Colonies grow in silt with base anchored to rocky substrate.

VARIATION: The paratypes differ in size (Figure $2 c-g$ ) but all have closely set lobes. There is variation in the degree of polyp retraction: Co 30545 (Figure $2 b-d$ ) has numerous protruding polyps, whereas Co 30562 (Figure 1e) and Co 30536 (Figure 1f,g) have retracted ones. All paratypes possess the same type of sclerites as the holotype.

ETYMOLOGY: The species name is derived from Latin, rubeusa (red), in reference to the color of the colonies.

remarks: The genus Paraminabea was established by Williams and Alderslade 


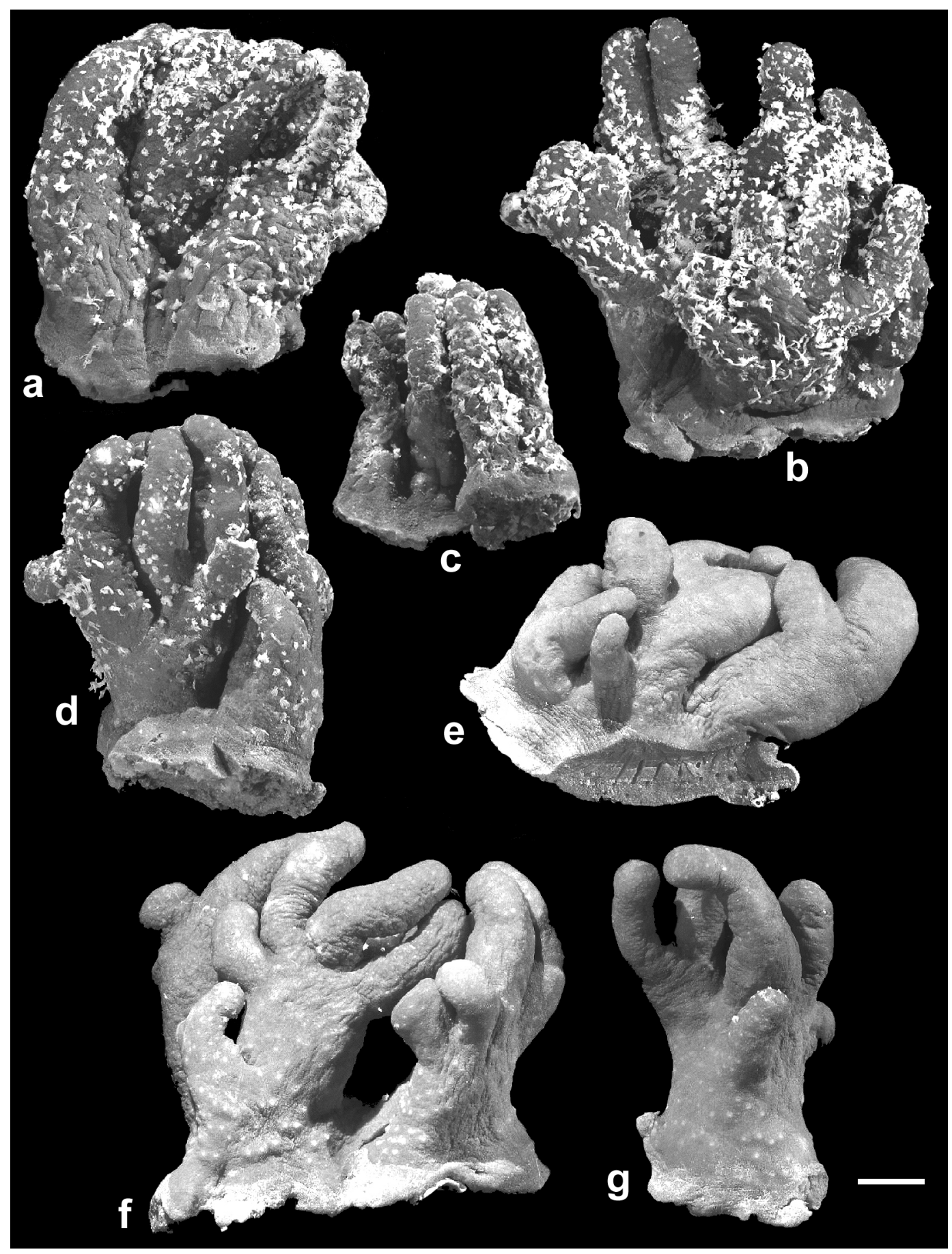

Figure 2. Paraminabea rubeusa Benayahu \& Fabricius, n. sp.: $a$, holotype (zmtau Co 30530); $b-d$, paratypes: zmtau Co 30545; e, zMtau Co 30562; $f$, zMTau Co 30536. Scale bar $10 \mathrm{~mm}$. 


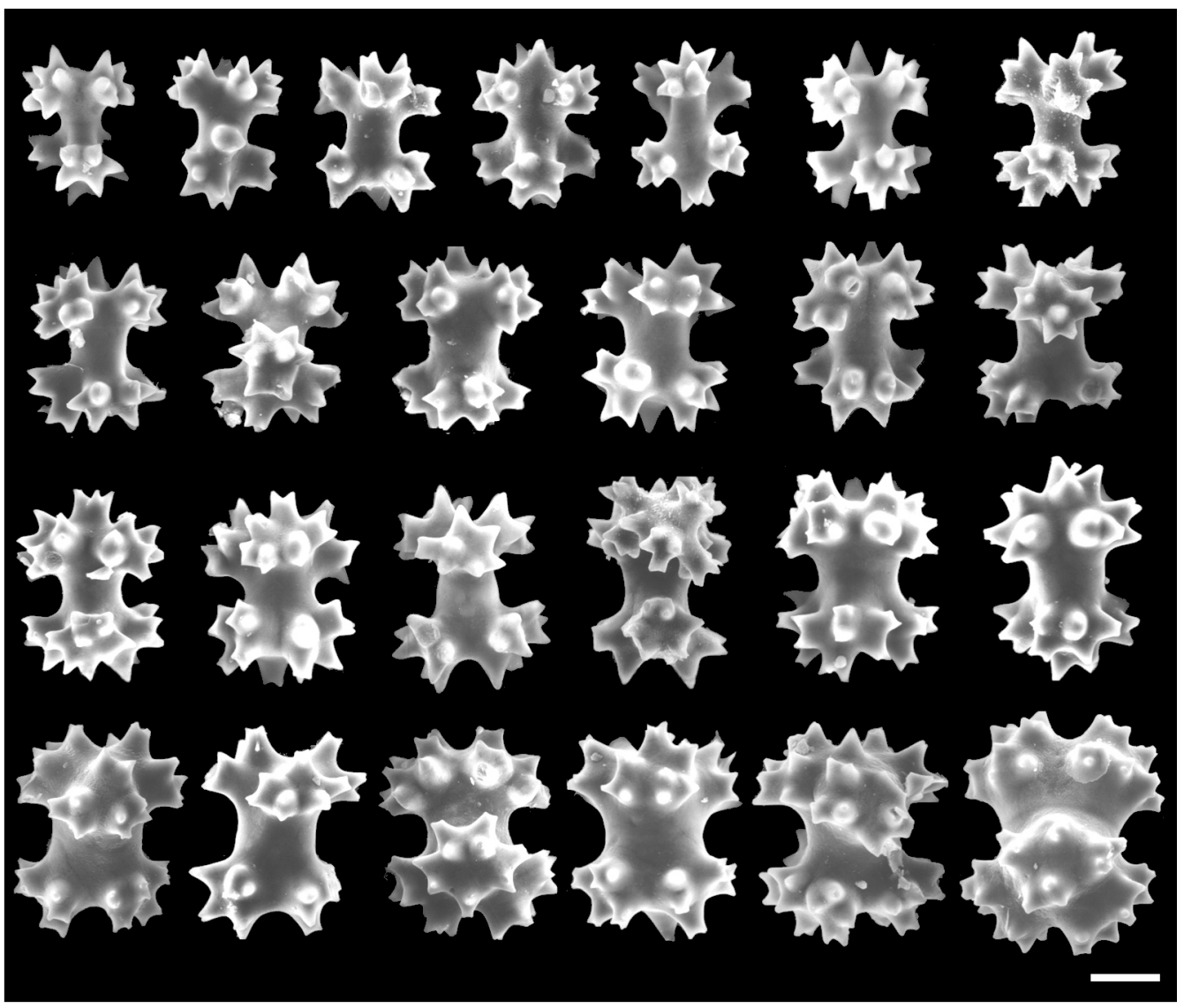

Figure 3. Paraminabea rubeusa Benayahu \& Fabricius, n. sp.: holotype (zmtau Co 34221), six- and eight-radiates of surface of the lobes. Scale $0.02 \mathrm{~mm}$.

(1999), referring to alcyoniid soft corals with dimorphic colonies commonly unbranched and dome-shaped or hemispherical to digitiform or, rarely, digitate/lobate with a few branching processes. Sclerites of surface or interior of colony are densely packed: mostly barrels and six- or eight-radiates; spindlelike forms derived from radiates and tuberculate spheroids may also be present. Paraminabea rubeusa, n. sp., fits the diagnostic features of Paraminabea Williams \& Alderslade, 1999, and thus raises to nine the number of species in this genus. Before this study, $P$. arborea Williams \& Alderslade, 1999, was the only digitate/branched species described in the genus. There are several differences between these two species. Paraminabea rubeusa, n. sp., has a more robust morphology, with closely set lobes (Figure 2). It also differs in its interior lobes possessing spindles with a distinct waist, whereas $P$. arborea Williams \& Alderslade, 1999, has mostly barrels and six- or eight-radiates. Paraminabea rubeusa, n. sp., has barrels in the base interior, and $P$. arborea Williams \& Alderslade, 1999, has similar sclerites that may resemble spheroids. It should be noted too that colonies of $P$. indica (Thomson \& Henderson, 1905) can also be lobate, with thick short lobes arising from a distinct stalk that occupies as much as half of the colony's total length (see Williams 1992), thus differing from P. rubeusa, n. sp. 


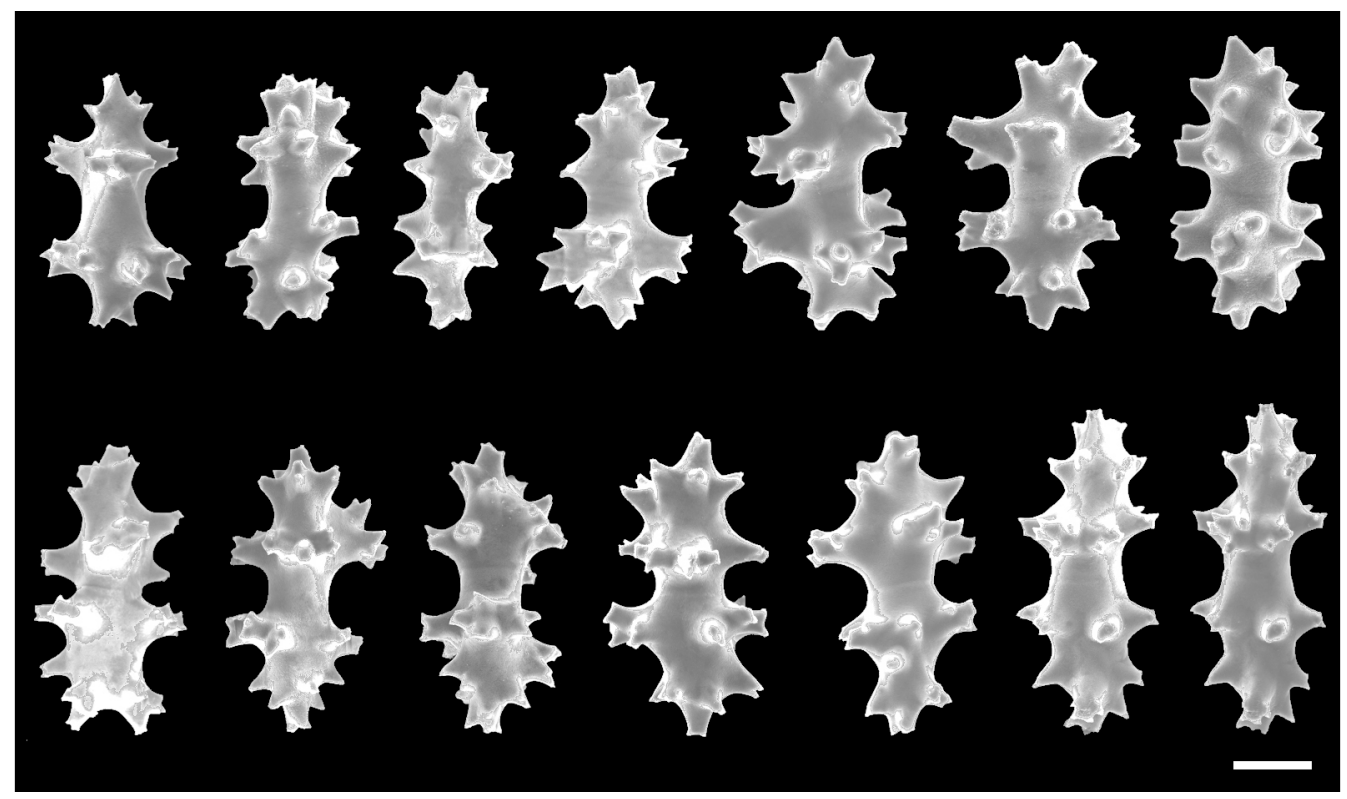

Figure 4. Paraminabea rubeusa Benayahu \& Fabricius, n. sp.: holotype (zmtau Co 34221), spindle like sclerites of interior of lobes. Scale $0.02 \mathrm{~mm}$.

In addition, these two species have differently shaped sclerites. Paraminabea rubeusa, n. sp., differs too from the recently described $P$. honkongensis Lam \& Morton, 2008, both in colony morphology and sclerites. Therefore, based on the above comparisons, it is evident that the examined specimens (Figure 2) have a unique morphology and sclerites and differ from all previously described congenerics. The recent findings of Lam and Morton (2008), along with ours reported here, further indicate a presumably high degree of endemism of Paraminabea species in the western Pacific, as was noted by Williams and Alderslade (1999).

\section{DISCUSSION}

The overall objective of this survey was to investigate the octocoral fauna of the families Alcyoniidae, Nephtheidae, and Xeniidae in Hong Kong. Our findings indicate an impoverished diversity of these three families (Table 1), which comprised only eight species distributed in seven genera. It should be noted that our collection also yielded ca. 70 samples of azooxanthellate octocorals of the family Nephtheidae and Nidaliidae, indicating their high abundance at the study sites (see also Fabricius and McCorry 2006). The latter included Scleronepbthya gracillimum (Kükenthal, 1906) (Figure 6b), and others not identified to species level from the genera Dendronepbthya (family Nephtheidae, Figure 6c), Chironephtbya, and Nephtbyigorgia (family Nidaliidae, Figure $6 d, e$ ). It is interesting that no zooxanthellate nephtheid taxa were found in our surveys. Moreover, the zooxanthellate species of the families Alcyoniidae and Xeniidae had a rather limited distribution on the studied reefs, and they constitute only a small part of the collection. This is demonstrated by the rarity on the reefs of Cladiella pachyclados (Klunzinger, 1887) and Cladiella digitulata (Klunzinger, 1887) (Figure 6f). In addition, this observation is further demonstrated by our finding that Sinularia brassica May, 1898 (Figure 6g), and S. inexplicita Tixier-Durivault, 1970, were the only species of their genus found in Hong Kong (Table 


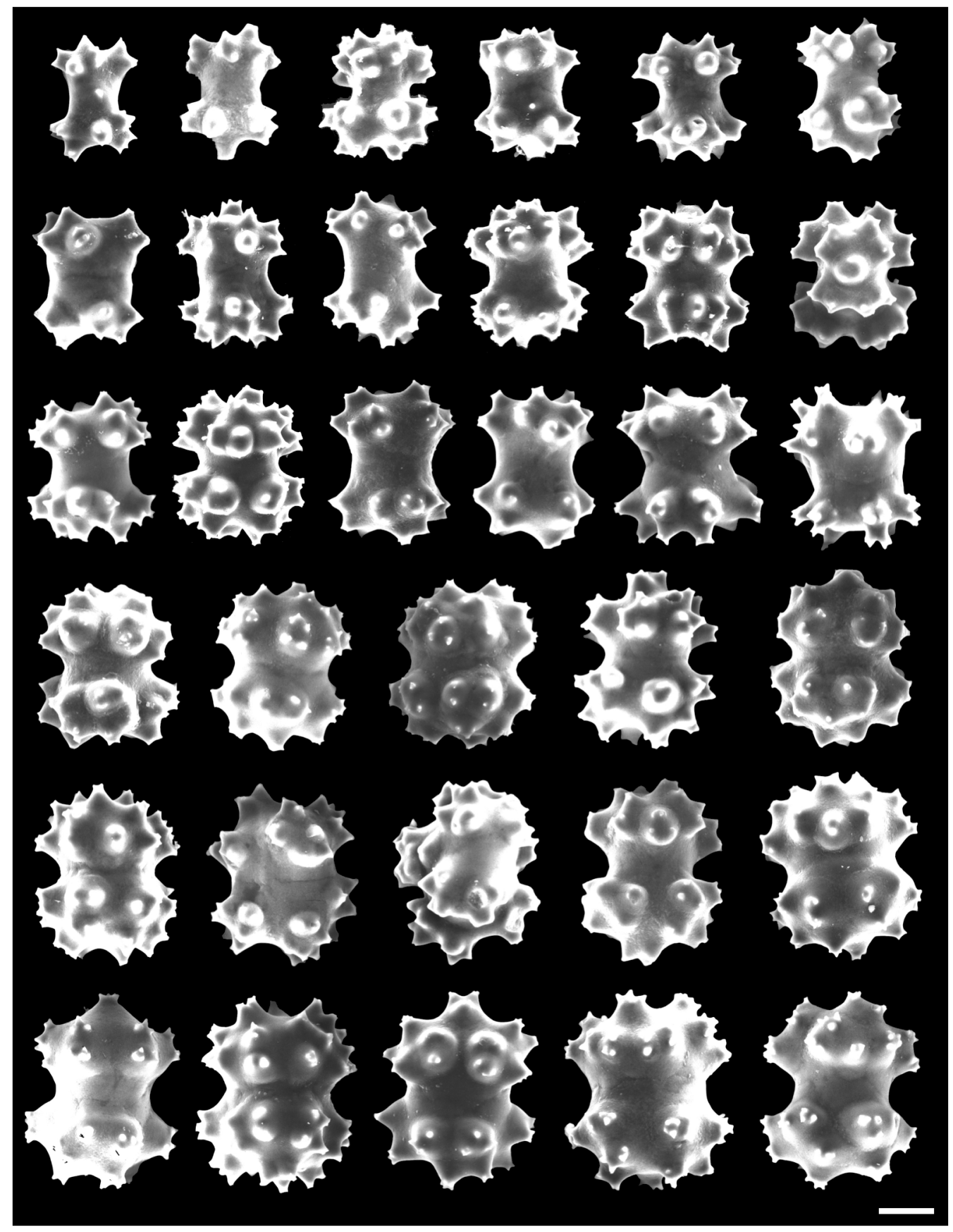

Figure 5. Paraminabea rubeusa Benayahu \& Fabricius, n. sp.: holotype (zmtau Co 34221), barrels and radiates of interior of the base. Scale $0.02 \mathrm{~mm}$. 

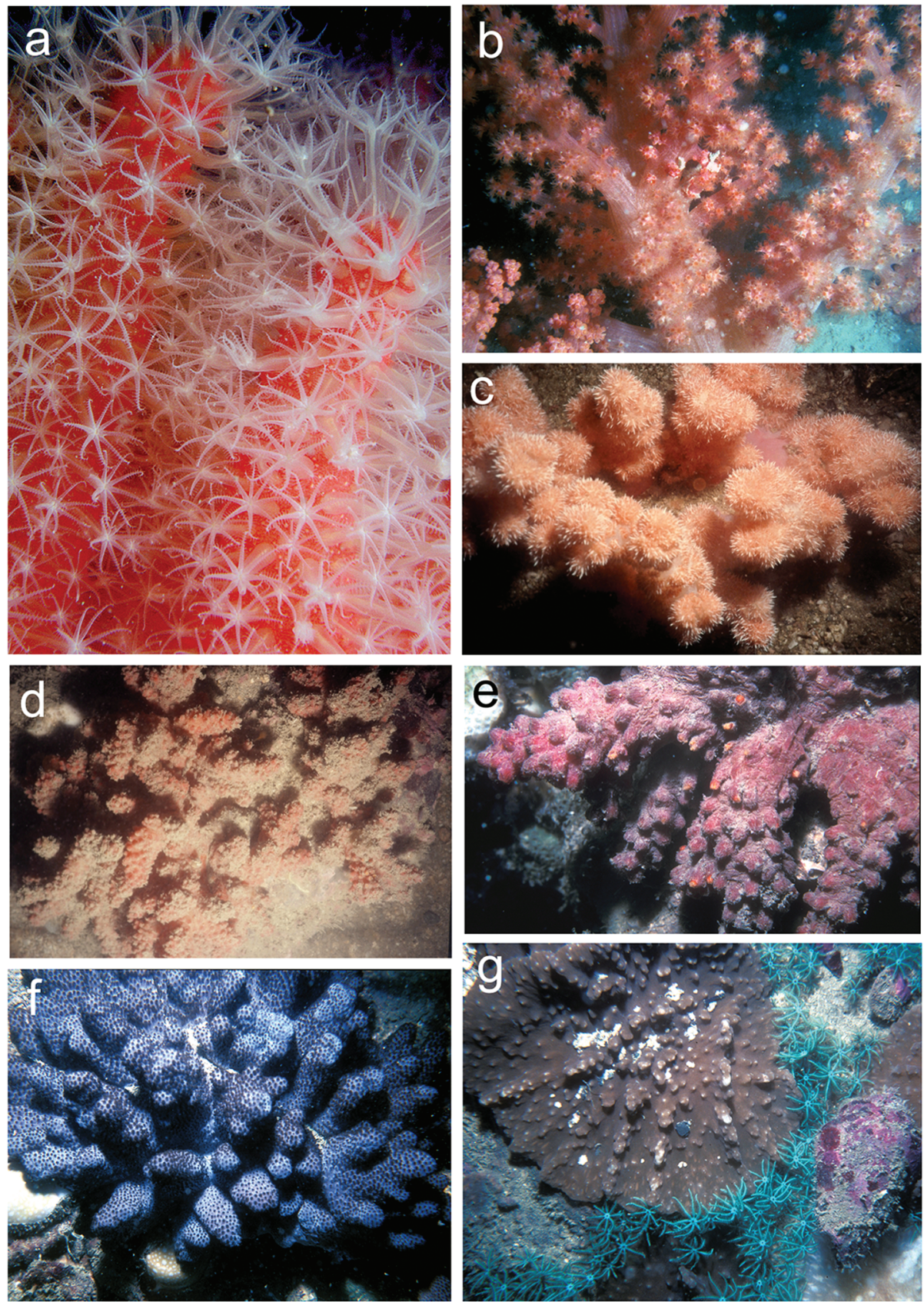

FIGURE 6. Underwater photographs of Hong Kong octocorals: $a$, Paraminabea rubeusa Benayahu \& Fabricius, n. sp., with expanded autozooids; $b$, Scleronephthya gracillimum (Kükenthal, 1906); c, Dendronephthya sp.; $d$, Nephthyigorgia sp. in part covered with sediment; $e$, Nephthyigorgia sp., closeup of branches; $f$, Cladiella digitulata (Klunzinger, 1887); $g$, Sinularia brassica May, 1898, and Sansibia flava (May, 1898) (bluish turquoise polyps). 
1), compared, for example, with 32 Sinularia species in the South China Sea (Ofwegen 2002), 30 in Taiwan (Benayahu et al. 2004), and 15 in Singapore (Y.B., unpubl. data). The impoverished nature of the Hong Kong zooxanthellate Alcyoniidae fauna is further demonstrated by the low number of species in the other recorded genera: Cladiella (two species), Lobophytum (one), and Sarcophyton (one), which typically contribute a much higher number of species in Indo-Pacific reefs (e.g., Ofwegen and Vennam 1994, Benayahu 1997, 2002, Fabricius and Alderslade 2001, Benayahu et al. 2004). Notably, our results are the first to report species of the genera Sarcopbyton and Sinularia for Hong Kong (see also Benayahu and Ofwegen 2009). Recently, Lam and Morton (2008) recorded 20 octocoral species from submarine caves there and listed a total number of 60 species already recorded from Hong Kong waters. Regrettably, that study did not include species of the families Alcyoniidae, Nephtheidae, and Xeniidae that had been recorded earlier for Hong Kong by Fabricius and McCorry (2006). Obviously, none of the species identified in the study reported here (Table 1) appeared in Lam and Morton's (2008) list. The poor zooxanthellate octocoral fauna of Hong Kong is further indicated by the presence of Sansibia flava (May, 1898) (Figure $6 g$ ) as the only species found there of the family Xeniidae (Table 1), whereas species of this family contribute substantially to the octocoral diversity in both the East and South China reef systems (e.g., Roxas 1933, Benayahu et al. 2004). It is suggested that it is the environmental conditions prevailing in Hong Kong that have caused the paucity of Xeniidae species there, which require highclarity water (see also Fabricius and McCorry 2006; Y.B., pers. obs.).

Some of the previous studies on Hong Kong Octocorallia contain confusing mistakes. For example, Shen (1940) wrongly assigned Dendronephthya sp. and Nephthea sp. from Hong Kong to the family Alcyoniidae and also misspelled some of the taxa (i.e., Octocoralla, Alcyonidae, Nepbthya). Later, Clark (1997) listed Dendronephthya gigantea (Verrill, 1864) and Eleutherobia indica (Thomson \&
Henderson, 1905) from Cape d'Aguilar Marine Reserve. Due to the lack of an appropriate revision of the genus Dendronephthya, in the study reported here we could not identify colonies of that genus with species in our collection or verify the appearance of $D . g i-$ gantea. Clark (1997) wrongly assigned D. gigantea (Verrill) to the family Alcyoniidae and listed E. indica (Thomson \& Henderson, 1905), which is not a known taxon. It is possible that the latter species was Paraminabea indica (Thomson \& Henderson, 1905).

Fabricius and McCorry (2006) indicated that the octocoral communities in Hong Kong comprised 42 species in 23 genera. Unfortunately Lobophytum depressum TixierDurivault, 1996, and Sarcophyton tenuispiculatum Thomson \& Dean, 1931, were wrongly identified by Y.B., but their correct identification is now presented in Table 1 (Lobophytum mortoni Benayahu \& Ofwegen, 2009, and Sarcophyton tumulosum Benayahu \& Ofwegen, 2009, respectively).

Li (1986) identified 10 species from Hong Kong belonging to four genera of the families Alcyoniidae [Cladiella bumesi Verseveldt, 1974; C. madagascarensis (Tixier-Durivault, 1944); C. subtilis Tixier-Durivault, 1970; Lobophytum denticulatum Tixier-Durivault, 1956; L. depressum Tixier-Durivault, 1966; and $L$. venustum Tixier-Durivault, 1957] and Nephtheidae (Spongodes spinifera Holm, 1895; S. studeri Ridley, 1884; Scleronephtbya corymbosa Verseveldt \& Cohen, 1971; and S. pustulosa Wright \& Studer, 1889). We found none of these species, and only $S$. pustulosa Wright \& Studer, 1889, was also found in the recent survey by Lam and Morton (2008).

It is striking that all of the species obtained in our study are either new species or new zoogeographical records for Hong Kong (Table 1). Species of the family Alcyoniidae are undoubtedly the best-known reefdwelling octocorals and are broadly distributed throughout the Indo-Pacific region (e.g., Fabricius and Alderslade 2001, Benayahu 2002, Ofwegen 2002). Members of this family are poorly represented in the Hong Kong reefs, however, and the record of surveys there (e.g., Li 1986, Lam and Morton 2008; this study) may suggest a decline in 
their richness over time and even the possible extinction of certain species, as reflected in the findings of $\mathrm{Li}$ (1986) compared with this study. Seawater quality has severely deteriorated in Hong Kong in the last few decades (Morton 1994), and its marine environment has been chronically polluted by sewage, land reclamation projects, industrial waste, contaminated sludge, trace metals, pesticides, and PCBs (McCorry and Cumming 1999, Fabricius and McCorry 2006, and references therein). The recent octocoral surveys there (Fabricius and McCorry 2006; this study) have indicated that Indo-Pacific typical shallow-water zooxanthellate octocoral communities are on the verge of disappearance from the Hong Kong reefs. Certain resilient species can nonetheless still cope with the environmental deterioration, and new ones are even being discovered there (Lam and Morton 2008; this study). In light of this finding, it is imperative to implement in Hong Kong effective conservation policies that will preserve the remaining octocoral fauna and prevent the local extinction of species, some of which may be endemic to the region.

\section{ACKNOWLEDGMENTS}

We thank L. P. van Ofwegen and two anonymous reviewers for comments on the manuscript. We are particularly grateful to B. Morton for initiating the octocoral survey and inviting us to carry out this research. We thank K. Lam and D. McCorry for advice and help during the fieldwork and the Swire Institute of Marine Science, The University of Hong Kong, for providing facilities. We thank Y. Delaria for valuable assistance with the scanning microscopy, A. Shoob for photography, V. Wexler for graphic assistance, A. Shlagman for professional curatorial skills, and N. Paz for skillful editorial assistance.

\section{Literature Cited}

Benayahu, Y. 1997. A review of three alcyonacean families (Octocorallia) from Guam. Micronesica 30:207-244.
- 2002. Soft corals (Octocorallia: Alcyonacea) of the southern Ryukyu Archipelago: The families Tubiporidae, Clavulariidae, Alcyoniidae and Briareidae. Galaxea JSRS 4:1-21.

Benayahu, Y., M.-S. Jeng, S. Perkol-Finkel, and C.-F. Dai. 2004. Soft corals (Octocorallia, Alcyonacea) from southern Taiwan. II. Species diversity and distributional patterns. Zool. Stud. 43:548-560.

Benayahu, Y., and L. P. van Ofwegen. 2009. New species of Sarcopbyton and Lobophytum (Octocorallia: Alcyonacea) from Hong Kong. Zool. Meded. (Leiden) 83:863-876.

Clark, T. H. 1997. The distribution of ahermatypic corals at Cape d'Aguilar, Hong Kong. Pages 219-232 in B. Morton, ed. Proceedings, 8th International Marine Biology Workshop: The Marine flora and fauna of Hong Kong and southern China, Hong Kong, 1995. Hong Kong University Press, Hong Kong.

- 1998. The distribution of hermatypic sceractinian corals at Cape d'Aguilar, Hong Kong. Pages 151-164 in B. Morton, ed. Marine biology of the South China Sea: Proceedings, 3rd Conference on the Marine Biology of the South China Sea, Hong Kong, 1996. Hong Kong University Press, Hong Kong.

Fabricius, K. F., and P. Alderslade. 2001. Soft corals and sea fans: A comprehensive guide to the tropical shallow water genera of the central-west Pacific, the Indian Ocean and the Red Sea. Australian Institute of Marine Science, Townsville.

Fabricius, K. F., and D. McCorry. 2006. Changes in octocoral communities and benthic cover along a water quality gradient in the reefs of Hong Kong. Mar. Pollut. Bull. 52:22-33.

Lam, K., and B. Morton. 2008. Soft corals, sea fans, gorgonians (Octocorallia: Alcyonacea) and black and wire corals (Ceriantipatharia: Antipatharia) from submarine caves in Hong Kong with a checklist of local species and a description of a new species of Paraminabea. J. Nat. Hist. 42:749-780.

Lam, K., P. K. S. Shin, R. Bradbeer, K. K. K. Ku, P. Hodgson, and S. G. Cheung. 2007. 
Baseline data of subtropical coral communities in Hoi Ha Wan Marine Park, Hong Kong, obtained by an underwater remote operated vehicle (ROV). Mar. Pollut. Bull. 54:107-112.

Li, C. 1986. The Alcyonacea in Hong Kong waters. Tropic Oceanol. 5:19-25.

McCorry, D. 2002. Hong Kong scleractinian coral communities: Status, threats and proposals for management. PhD. thesis, The University of Hong Kong, Hong Kong.

McCorry, D., and R. L. Cumming. 1999. Hong Kong's coral communities: Surviving adversity. Coral Reefs 18:408.

Morton, B. 1994. Hong Kong's coral communities: Status, threats and management plans. Mar. Pollut. Bull. 29:74-83.

. 2002. Effects of extreme rainfall, typhoons and declaration of marine reserve status on coral bleached at Cape d'Aguilar (1998 and 1999). J. Mar. Biol. Assoc. U. K. 82:729-743.

Morton, B., and G. Blackmore. 2001. South China Sea. Mar. Pollut. Bull. 42:12361263.

Nutting, C. C. 1910. The Gorgonacea of the Siboga Expedition. III. The Muriceidae. Siboga Expedition Monograph 13b:1-108.

Ofwegen, L. P. van. 2002. Status of knowledge of the Indo-Pacific soft coral genus Sinularia May, 1898 (Anthozoa, Octocorallia). Proc. 9th Int. Coral Reef Symp., Bali, 2000. Vol. 1:167-171.

Ofwegen, L. P. van, and J. Vennam. 1994. Results of the Rumphius Biohistorical Expedition to Ambon (1990). Part 3. The Alcyoniidae (Octocorallia: Alcyonacea). Zool. Meded. (Leiden) 68:135-158.

Roxas, H. A. 1933. The Philippine Alcyonaria: The families Cornulariidae and Xeniidae. Philipp. J. Sci. 50:49-110.
Shen, C.-J. 1940. The spicular corals of Hong Kong. J. Hong Kong Fish. Res. Sta. $1: 272-277$.

Stimpson, W. 1855. Description of some of the new marine invertebrates from the Chinese and Japanese seas. Proc. Acad. Nat. Sci. Phila. 7:375-384.

Verrill, A. E. 1865a. Synopsis of the polyps and corals of the North Pacific Exploring Expedition, under commodore C. Ringgold and Captain John Rodgers, U. S. N., from 1853 to 1856 . Collected by Dr. Wm. Stimpson, naturalist to the Expedition. With descriptions of some additional species from the West Coast of North America. Proc. Essex Inst. 4:181-196. . 1865b. Classification of polyps: (Extract condensed from a synopsis of the Polypi of the North Pacific Exploring Expedition, under Captains Ringgold and Rodgers, U. S. N.). Proc. Essex Inst. 4:145-152.

Williams, G. C. 1992. Revision of the soft coral genus Minabea (Octocorallia: Alcyoniidae) with new taxa from Indo-West Pacific. Proc. Calif. Acad. Sci. 48:1-26.

Williams, G. C., and P. Alderslade. 1999. Revisionary systematics of the Western Pacific soft corals genus Minabea (Octocorallia: Alcyoniidae), with descriptions of a related new genus and species from the Indo-Pacific. Proc. Calif. Acad. Sci. 7:337-364.

Zou, R. L., and P. J. B. Scott. 1982. The Gorgonacea of Hong Kong. Pages 135-159 in B. Morton and C. K. Tseng, eds. Proceedings, 1st International Marine Biology Workshop: The marine flora and fauna of Hong Kong and southern China, Hong Kong. Hong Kong University Press, Hong Kong. 